\title{
A Study on Perception of Employees during Change in an Organization
}

\author{
E. Rebeka \\ Research Associate, VIT Business School, VIT University, Vellore, Tamilnadu, India \\ Email: rebeka.e@vit.ac.in \\ Dr. R. Indradevi \\ Associate Professor, VIT Business School, VIT University, Vellore, Tamilnadu, India \\ Email: rindradevi@vit.ac.in
}

\section{Doi:10.5901/mjss.2015.v6n1p72}

\section{Abstract}

Any business in today's dynamic situation that is looking for the pace of change to slow down is likely to be sorely disappointed. In fact, businesses should embrace change. Change is very important for any organization since changes are undertaken by altering. It is complex for any organizations, specifically for top management as, to get ready and direct the change in behavior that influence the stress of both the organization and its employees business would rationally going to lose their active limit and be unproductive to gather the requirements of people. It is difficult for organizations to avoid change, as new ideas promote growth for them and their members. So this study approaches to examine the employees' perceptions or attitude towards change implemented in their organization. Data was collected from a sample of 60 employees from a manufacturing industry and the result is presented in the paper.

Keywords: Perception, Organizational Change, Attitude, fear, career enhancement

\section{Introduction}

\subsection{Perception}

This paper makes a strong to a prominent step with perception and reaction to change, it is chiefly extensive to connect on the circumstance and offer of perceptions on choice. Even though study on perceptions is loaded and inclusive, the meaning of this prose evaluate is not to present an in-depth list of presented definitions of perception. As a different, my plan is to submit two key points.

1. Perception, as a sensitively factor, it organized with other assemble such as activities or mental power. Still it's the variation between these raise, the larger part, if not all, of them seem to contribute to regular assets that shall be seen in a while.

2. Perceptions pressure the ways in which human realize the world in the region of them and how they make assessment. With deeper insights into how people be aware of the world, we can better understand the ways in which humans make decisions and why they act in specific ways.

Perception can be defined as a "multipart course by which people choose, systematize, and understand sensory inspiration into a significant and logical image of the world" (Berelson and Steiner, 1964: 88). In the similar layer, perception is "concerning in receipt of, select, acquire, transform and organize the sequence completed by our mind" (Barber and Legge, 1976). The discover on perceptions can be reveal annul to Bartlett's (1932) imperative facility on the hopeful behavior of knowledge, which differ that description offer to manage individual accepting the behavior of person regular perspective about the globe influence and quality in series process. A activity by Anderson and Paine (1975) has posited the authority of the perception of uncertainty in the environment on the perception of the need for change in a organization strategy.

The study on the role and possessions of perceptions on employee choice and approach is so extreme to be trained and the lookout for accepting of various perceptions on employees behaviors such as returns or dedication in the field of human resource management keep on its force. Though, experimental research has initiate to show that in organizational locations, certain perceptions such as perception of uncertainty are linked with employee behaviors. An investigational study by Ashford (1989), he has shown details for a optimistic relationship between supposed job 
uncertainty and purpose to leave.

In other hand Eisenberger, Fasolo and Davis-LeMastro (1990) has deep-rooted thought on employees' assumption that organization maintains their interrelation with mixture of attitude and behaviors. In a latest study, Gopinath and Becker (2000) found that apparent practical justice relating to the divestment activities of the firm is hopefully related to post-divestment eagerness of the firm. If perceptions are resulting from or based on unfinished sequence and some degree of inspection, perceptual bias will occur, and thus influence a person's decision and events. Here, it is the disputation that several perceptions of change are acting as determinants of employees' reactions to change. That is, humans usually try to make sense of what has happened, what is happening, and what will happen.

A number of researchers have noted a link between the perceptual process and the understanding of information; they have argued that the understanding of information is based on the perceptual process Anderson and Pained (1975). During organizational change process, employees create their own perspective and interpretation of what is going to happen, what ideas of others, and how they are believed.

\subsection{Organizational Change}

Organizational change takes place when a company makes a development from its present state to some preferred opportunity. Managing organizational change is the process of forecasting and realization change in organization in such a way as to reduce employee struggle and cost to the organization while at the same time maximizing the value of the change effort. From an energetic perception organizational change occurs as an effect to an ever-changing environment or as a response to a current urgent situation. Change is an approach of changing/transitioning individual's teams. It is an organization process planned at helping stakeholders to accept and hold change in their business environment and in their insignificant lives.

\subsubsection{Organizational need and importance}

Large series of past research on organizational change has focused on four main categories. One category has to do with content issues, and it mainly focuses on factors related to successful or unsuccessful change attempts (e.g., Hofer 1980; Bibeault, 1982; Hambrick and Schecter, 1983; Barker and Duhaime, 1997). Another category concerns process issues, mainly focusing on steps, phases, or actions undertaken during the implementation of an intended change (e.g., Judson, 1991; Kotter, 1995; Galpin, 1996). An additional category deals with context issues, focusing on internal or environmental forces or conditions affecting a change in an organization (e.g., Schendel and Patton, 1976; Slatter, 1984; Robbins and Peace, 1992). The final category concerns reaction issues, and it focuses on employees' responses to organizational change (e.g., Weiss and Cropanzano, 1996; DeWitt, Trevino, and Mollica, 1998; Patterson and Cary, 2002).

\section{Review of Earlier Studies}

\subsection{Perception/Attitude of Employees on Change}

Attitude has been determined usually for a wide stage of time. It mainly focuses on attitudes fear of the behavior and activity of manners and how individuals make them. The purpose of recent information on attitude to trade setting and the implication of attitude for individuals' decision and behaviors are of attention in this paper, that employee' attitudes can influence their tendency to originate a prearranged reaction to a change.

In collective psychology, the term "attitude" refers to an individual's liking for or hesitation toward a plan, issue, item or entity; it is prejudiced in nature, and can be positive or negative. There are three other definitions that have prejudiced following studies on attitude. One definition is that attitude is "the influence for or against an emotional object".

Thurstone, (1931) defined attitude as a manipulate for location. Business should commonly focus on planned change. To overcome resistance to change, organization should prepare a clear arrangement and change awareness among employees in order to generate well planned work surroundings and in proportion work agenda to reduce pressure and insecurity.

Another definition that seems to be more comprehensive is that attitude is "a psychological and neural state of willingness, organized through experience, exerting a instruction or active influence upon the individual's response to all objects and situations with which it is related" (Allport, 1935: 8). 
Attitudes towards organizational change may be defined as an employee's overall positive or negative evaluative decision of a change proposal implemented by their organization (Elias, 2009). It is the inner state that influences individual's alternative of personal action, or a response propensity towards the change (Bianey, et al., 2004). It is the certain regularities of an individual's feelings, thoughts and inclination to act towards some aspect of his or her environment (Visagie, 2010).

Organizational policies and strategies have to be changed due to the rising globalization of industries, growing opposition and scientifical progression (Hampel \& Martinsons, 2009). Most challenges in organizations are generated by competition, advanced technology, fusion, development, product quality safeguarding, attractive employee efficiency, rapid growth, new business ventures, thrilling opportunities, innovations, and new leadership and management approaches (Madsen et al., 2005). For these challenges to be overcome, employee attitudes and behaviors to accept organizational change should be taken into account by management and change agents for successful organizational change to be achieved (Bernerth, 2004).

The capabilities of managers, employees and work environment are examined by organizational change that affects employee attitudes and behaviors by turning a situation from the known to the unknown. Some researchers focused on change that may have a serious negative impact on employee attitudes (Weber \& Weber, 2001). Therefore, creating employee positive attitudes boosts the readiness of employees as an important factor for successful organizational change (Rafferty \& Simon, 2006; Bareil et al., 2007).

Ming-Chu Yu (2009) investigated that employee perception of organizational change and how individual's perceptions are shaped by faith and stress management strategy. Four hundred and five analyzable surveys were drived that employees of four taiwaness governmental departments undergoing change. These surveys were conducted within the ministry of National defense, the coast guard management, the national police agency, and the national fire agency. Consequences illustrated that organizational change had a important negative force employees belief and work attachment. Though, stress management strategies and a perceptive of organizational change can positively direct employee's organizational recognition and job attachment. As a outcome it is optional that stress management training be union within an organization undergoing change in command to offer strategies for stress release and to get better employees organizational recognition and job concern.

As it involves values, preferences, and attitudes toward a particular activity human part of the organization becomes a major challenge in handling change processes in the organization. It is difficult to change attitudes as people are generally more comfortable with what they have learned or knew due to stereotyping, fear of taking risks, intolerance to ambiguity, and possibly the need to maintain tradition (Carnall, 1990). For any change to be effective, people's beliefs, and attitudes must be challenged and clarified because significant and sustainable change relies on the human system at the core of every business system (Juechter et al., 1998).

Mowday et al. (1982) conceived commitment as an attitude reflecting the nature and quality of the linkage between an employee and an organization. It is an individual's identification with a particular organization and its goals to maintain membership in order to attain these goals. The most important determinant of attitudes/perception towards organizational change. In other words, employees with high organizational commitment are more willing to exert more effort in a change project and, therefore, it is more likely to develop positive attitudes towards organizational change. Organizational commitment influences certain attitudes toward organizational change, and job satisfaction with certain facets of job directly and indirectly influences the different dimension of attitudes toward organizational change (Yousef, 2000).

Karyn E. Trader-Leigh (2001) projected that change and organization transformation is a rigid effort. Change fails because surroundings are not ready to agree to change and do not well look forward to the strength on individual system. Individuals' personal and emotional impact and domination of norms, traditions, compatibility and supporting factors are the reasons to individual resistance to change. Maria Vakalo (2005) detailed of professional pressure related to negative attitudes to change. Tension created by difficult task related to burden and unfair pay, can cause negative attitude towards organization change and therefore reside in change process.

According to West wood, (1984), Gottfried (1994) and Thomas and David (2005) not only male employee's attitudes are changing during change implementation in the organization but women employees are also mostly conflicted to change in everyday practice. Leanne catcher, (2009) understood that the organization change influences the attitude of both the gender according to the workplace and it entitled the things which traditions and situation, where employees resists change that determine the job fulfillment and lack of confidence for the work.

Myungweaon choi (2011) in his paper discussed that organization are gradually required to advance in their capacity to improve employees hold on organizational change. Researchers have determined on various attitudinal constructs that represent employee's attitude towards organizational change. Change is not an incident divorced from organizational conditions from which the change appears. The history of change in the organization surely plays an 
important role in determining employee's attitudes towards organizational change. Though HR consultants need to describe the past disappointment entirely and support system and policies proper in initiating change. So, this helps for further perceptions to sustain involvement and belief among employees by encouraging open communication, presenting guidance and execute the job required. So, HR practitioners provide sufficient guidance's for employees and improve employee's assurance in their own capability to providing somewhere to continue a particular change initiative.

Cynthia Wittig (2012) afforded a model that demonstrated the practice of how employees' reaction to change was created. Quite a few theories were supported that change has come through different stages to initiate change (Lewin 1951). Based on the knowledge of both authors with change enterprises in the travel industry and scientific literature, the dispute that change does not occur in separate phases is offered. Rather change occurred as a flow of process and events that is not standing.

The author concluded that for accomplishing change successfully the role of employees is extremely core, and employees are highly imperative and employees reaction to change are prejudiced by a number of features, including employees' feeling and cognitions, declaration, and involvement in opinion making. Change a driving force that can be related to variety of employee's reactions in organizational change as an exclusive model that demonstrated how employees respond to change. In this paper the author provided that OD practitioners offer a vital sequence about employees' reactions to change, and organizations would promoted for advance research in this field.

Lan Coa, (2013) opined employee attitude is proactively determined by the environment and their individual objective and morals. Hechanava (2003) said that in order to make change valuable, employees need to feel sufficiently skilled and knowledgeable in particularly during change supportive statement which would reduce panic and doubt and therefore, opposition to change.

According to theoretical evidence organizational change causes certain employee attitudes, behavior, and perception that in create assurance to the organization and is always connected with the organization growth/development. Some studies linked employee perceptions of career related like inner quality of being, employee safety, guidance and improvement are mostly connected to emotion more than others activities like communication, participation and relations with supervisor (Gaertner and Nollen, .3 1989). Employee perception of precision of the advantage in evaluating method and equality of support contributed to the forecast of involvement (Ogilvie, 1986). Employee involvement is linked between HR practices and employee attitudes are inner connected with perception of the organization's promise to the profit of employee, like training and promotion etc. (Ebay et al.2000) employees perceptions of willingness for managerial change can provide to make easy or challenge an organizational change effort.

\section{Research Objective}

1. To understand the demographic details of the study respondents.

2. To study the perception of employees during change.

\section{Methodology}

A structured questionnaire was used in the survey that portrayed the perception of employees during change. The questionnaire used in the present study is based on the literature from Bryan \& Locke (1967), Latham \& Baldes (1975), Latham \& Kinne (1974), Latham \& Yukl (1975), Ronan, Latham, \& Kinne (1973), Herzberg \& Frederick (1968), Myers (1970), Raja (1974).

In a continuous struggle to remain competitive, manufacturing companies try to boost performance, improve quality and cut costs. In order to achieve that, manufacturing companies go in for continuous change in their process. Change management is an on-going process whereby the current state is determined to be inadequate. This change has an impact on the employees. The attitude or perception of employees towards this change process plays a major role in the organization. Hence the researchers intended to do this study with special reference to manufacturing industries.

The responses were collected from the employees of the one private manufacturing organization in Vellore district. Employees of the private manufacturing organization were selected through convenient sampling. The study used 5 point likert scales with closed ended questions ranging from strongly agree to strongly disagree. A total of 30 items was used for this survey excluding demographic characteristics.

The statistical package for social science (spss, version 20) was used to analyze the data. The reliability test has been conducted to verify the internal consistency of the variables obtained in the sample. The cronbach's alpha is found to 0.852 , which is much higher than the minimum acceptable level suggested by Nunally (1978). 


\section{Data Analysis and Interpretation}

A simple frequency test was done to understand the distribution of demographic details of the respondents.

\subsection{Demographic Characteristics Of The Study Participants}

Table 5.1.1: Demographic Characteristics Of The Study Participants [N=60]

\begin{tabular}{|c|c|c|}
\hline Demographic Variables & Frequency & Percent [\%] \\
\hline \multicolumn{3}{|c|}{ Gender } \\
\hline Male & 41 & $68.3 \%$ \\
\hline Female & 19 & $31.7 \%$ \\
\hline & 6 & $10.0 \%$ \\
\hline 2-4 years & 9 & $15.0 \%$ \\
\hline 4-6 years & 21 & $35.0 \%$ \\
\hline 6-8 years & 24 & $40.0 \%$ \\
\hline More than 8 years & 1 & $1.7 \%$ \\
\hline 21-25 years & 9 & $15.0 \%$ \\
\hline 26-30 years & 24 & $40.0 \%$ \\
\hline 31-35 years & 26 & $43.3 \%$ \\
\hline More than 35 years & & \\
\hline
\end{tabular}

It is inferred from the above table that from 60 respondents, $41(68.3 \%)$ are male and $19(31.7 \%)$ are female respondents. The sample is representative of all age groups. Majority of the respondents (43.3\%) are of the age group among 35 years above. When experience of the respondents is considered it is understood from the table above that nearly half of the sample (40.0\%) of the respondents have more than 8 years of experience. Thus it is clear that the study has generated responses from varied range of respondents adequately representing the diversity of the total population of employees of the selected manufacturing industries.

The reliability test was conducted for all 30 items and the cronbach's alpha is found to 0.852 which is presented in Table 5.1.2

Table 5.1.2: Reliability Statistics

\begin{tabular}{|c|c|}
\hline Cronbach's Alpha & No of Items \\
\hline 0.852 & 30 \\
\hline
\end{tabular}

Being satisfied with the reliability of the instrument, the researcher carried out the item to total correlation to identify and remove any item that deviated in value. Finally from 30 items only 18 items were retained by the researcher after removing the deviated items which is summarized in Table 5.1.3. An improved alpha value of 0.876 was obtained on the 18 items.

Table 5.1.3: Scale Reliability

\begin{tabular}{|c|c|}
\hline Cronbach's Alpha & No of Items \\
\hline 0.876 & 18 \\
\hline
\end{tabular}

\subsection{Factors for Perception}

After deciding on the 18 items for perception, factor analysis was carried out to identify the underlying factors of employees perception. But before proceeding on with factor analysis, few preliminary tests like Kaiser Meyer-Olkin measure of sampling Adequacy (.517) was done to justify that factor analysis is an appropriate tool for the present study. Kaiser (1974) recommends accepting values greater than 0.5 as acceptable. 
Table 5.2.1: KMO and Bartlett's Test

\begin{tabular}{|ccc|}
\hline \multicolumn{2}{|c|}{ Kaiser-Meyer-Olkin Measure of Sampling Adequacy. } & .517 \\
& Approx. Chi-Square & 839.268 \\
Bartlett's Test of Sphericity & Df & 435 \\
& Sig. & .000 \\
\hline
\end{tabular}

KMO and Barlett's test of sampling adequacy is 0.517 for perception

There are two stages in factor analysis. Stage one being the factor extraction process, wherein the objective of the study is to identify how many factors are to be extracted from the data. The result of the factor analysis is provided see Table 5.2.2. We find 5 factors in perception extracted together account for $69.234 \%$ of the cumulative variance (information contained in the original 5 variables)

Table 5.2.2: Extraction Method: Principal Component Analysis.

Rotated Component Matrix (a)

\begin{tabular}{|l|c|c|c|}
\hline Variables & Factor Loading & Factor Alpha & Factor Mean \\
\hline Factor 1 Employee Skill Development & & .715 & 3.578 \\
\hline Very confident at learning and developing new skills in job & .765 & & \\
\hline Certain about future career picture in the organization & .742 & & \\
\hline Change gives greater sense of control of job & .718 & & \\
\hline Factor 2 Employees involvement in change & & .491 & \\
\hline Organization values contributes to its well-being & .664 & & \\
\hline Colleagues have better opinion before the change & .656 & & \\
\hline No chance of giving opinions on change to decision makers & .515 & & \\
\hline Two way communication on decision making process & .809 & & \\
\hline Some changes within any organization from time to time & .524 & & \\
\hline Factor 3 Employees Trust & & .4730 \\
\hline Cooperation with organization on change & .873 & & \\
\hline Change is acceptable & .792 & & \\
\hline Procedures used for making change decisions & .577 & & \\
\hline Expressing the view on change & .774 & & 3.383 \\
\hline Trust top management & .858 & & \\
\hline Factor 4 Fear on change consequences & & .579 & \\
\hline Known consequences of change frighten & .812 & & \\
\hline Sense of resistance to change among colleagues & .547 & & \\
\hline New job at same level with another organization & .517 & & \\
\hline Factor 5 Career Enhancement & & .624 & \\
\hline Change enhances position in the organization & .521 & & \\
\hline Change gives more power to do job & & & \\
\hline
\end{tabular}

\subsection{Factor 1}

Three items like confident at learning and developing, future career and greater sense of control were loaded under factor one with loading range from 0.76 to 0.71 . The alpha value for the first factor is .715 and the mean value is 3.578 which indicated that there is a strong level of agreement among the respondents for factor one. The items loaded under factor one identify with the importance of learning and developing skills of employees. Hence factor one was named as skill development.

\subsection{Factor 2}

Five items like provision organization values, opinion before change, change to decision makers, two-way communication and change within organization were loaded under factor two with loading range from .66 to .52. The alpha value is .491 and the mean value is 3.320 which indicated that there is a strong level of agreement among the respondents for factor two. The items loaded under factor two understand the importance for decision making process. Hence factor two was 
named as Involvement in change.

\subsection{Factor 3}

Five items like co-operate with organization, change is acceptable, procedures for change decision, expressing the views and trust on top management were loaded under factor three with loading ranging from .87 to.85. The alpha value is .473 and the mean value is 3.740 which indicated that there is a strong level of agreement among the respondents for factor three. The items loaded under factor three identify with the importance on the cooperation of employees with management for implementing change. Hence factor three was named as Employees Trust on management.

\subsection{Factor 4}

Three items like consequences of change process, sense of resistance and job at same level were loaded under factor four ranging .81 to .51 . The alpha value is .579 and the mean value is 3.383 which indicated that there is a strong level of agreement among the respondents for factor four. The items loaded under factor four encountered the uncertainty and uncomfortable attitude of employees on change. Hence factor four was named as fear on change consequences.

\subsection{Factor 5}

Two items like enhance the position in the organization and power of job were loaded under factor five ranging from .66 to 52 . The alpha value is .624 and the mean value is 3.517 which indicated that there is a strong level of agreement among the respondents for factor five. The items loaded under factor five have compassion on employee development. Hence factor five was named as career enhancement.

\section{Conclusion}

Increasing diversified markets have a wide variety of needs and expectations that must be understood by organizations to become strong customers and collaborators. Organizational change is undertaken to improve the performance of the organization. Companies that refuse to embrace change may disappear. Change is difficult because it involves modifying people's attitude and behavior. Resistance comes from employees who are generally skeptical of change initiatives. Successful organizational change requires top management a clear explanation of how the contemplated changes can help employees to do their job's more efficiently and improve their carrier. This study concluded that employees attitude towards organizational change was both positive and negative. To make the employees overcome resistance and negative attitude towards change this recommended that management provides adequate change communication to enhance employee's motivation. It is recommended that top management expand the bottom up communication, to involve employees who have potential capability to influence the change process or to provide real input for future decisions.

\section{References}

\section{Reference to a journal publication}

Allport, G.W. (1935). Attitudes, In, C. Murchison (Ed), Handbook of social psychology: Worcester, M.A: Clark University press. Anderson, C. R., \& Paine, F. T. 1975. Managerial perceptions and strategic behavior. Academy of Management Journal, 18:811-23. Ashford, S., Lee, C. \& Bobko, P. 1989. Content, causes, and consequences of job insecurity: A theory-based measure and substantive test. Academy of Management Journal, 32: 803-829

Barber, P. J., \& Legge D. 1976. Perception and information. London: Methuen.

Bartlett, F. C. 1932. Remembering: A study in experimental and social psychology, Cambridge, UK: Cambridge University Press. Berelson, B., \& Steiner, G. A. 1964. Human behavior: An inventory of scientific findings, New York, NY: Harcourt, Brace \& World. Bernerth, J. (2004). Expanding Our Understanding of the Change Message. Human Resource Development Review, 3(1), 36-52. Bianey, C., Ulloa, R., \& Adams, S. (2004). Attitude Toward Teamwork and Effective Teaming. TeamPerformance Management, 10(7/8), 145-151.

Carnall, C. A. (1990). Managing Change in Organizations, Prentice-Hall International (UK). Hemel Hempstead.

Cynthia wittig, (2012) Employee reactions to organization change,OD practitioner,Acdemic journal spring 2012,vol.44 issue 2, p23.

Eby,L.T Admas,D.M Russelli,J.E.A and Gaby S.H(2000) Perception of Organizational readiness for change:factor related to employees 
reaction to the implementation of team-based selling. Human Relation Vol.53 No.3 pp.419-28

Eisenberger, R., Fasolo, P., \& Davis-LaMastro, V. 1990. Perceived organizational support And employee diligence, commitment, and innovation. Journal of Applied Psychology, 75: 51-59.

Elias, S. (2009). Employee Commitment in times of Change: Assessing the Importance of Attitudes towards Organizational Change. Journal of Management, 35(1), 37-55.

Gaertner, K. N. \& Nollen, S. D. (1989). Career Experiences, Perceptions of Employment Practices, and Psychological Commitment to the Organization. Human Relations, 11, 975 - 991.

Gopinath, C., \& Becker, T. E. 2000. Communication, procedural justice, and employee attitudes: Relationships under conditions of divestiture. Journal of Management, 26(1):63-83.

Hampel, P., Maris, S., \& Martinsons, G. (2009). Developing International Organizational Change Theory Using Cases From China. Human Relations, 62(4), 459-499.

Hechanova, R. et al., (2003). Antecedents and consequences of employees adjustment to oversea assignment: A meta-analytic review, Applied psychology: An International Review, vol. 52, Iss. 2, pp. 213-236.

Juechter, W. M., Caroline, F., \& Alford, R. J. (1998). Five Conditions for High performance Cultures. Training and Development, 52(5), 63-7.

Kaiser, H.F. (1974), An index of factorial simplicity, Pschometrika, 39, pp.31-36

Karyn Trader-Leigh, W. (2001). Resistance to organizational change: The role of cognitive and affective processes, Leadership \& organization development journal, vol. 22, Iss. 8, pp. 372-382.

Lan cao. (2013). The positive effects of a protean career attitude for self-initiated expatriates, vol. 18, Iss. 1, pp. 56-77.

Leanne Catcher, (2009). Resisting change from within and without the organization, Journal of organizational change, vol. 22, Iss. 3, pp. 275-289.

Madsen, S., Miller, D., \& John, C. (2005). Readiness for Organizational Change: Do Organizational Commitment and Social Relationships in the Workplace Make a difference? Human Resource Development Quarterly, 16(2), 213-234.

Maria vakola \& Ioannis Nikolaou (2005). Employee relations, Athens University of economics and business, vol. 27, Iss. 2, pp. 160-174.

Ming-chu Yu (2009) Employees' perception of organizational change: The mediating effects of stress management strategies public personnel management, vol.38,No.1, spring

Mowday, R., Porter, L., \& Steers, R. (1982). Employee-Organization linkages: The Psychology of Commitment, Absenteeism, and Turnover. New York: Academic Press.

Myungweon Choi (2011) Human Resource Management, Vol. 50, No. 4, Pp. 479 - 500, 2011 Wiley Periodicals, Inc. Published online in Wiley Online Library

Nunnally, J.C., (1978), Psychometric Theory (2nd ed.), New York, McGraw-Hill

Ogilvie, Marilyn (1986). Women in Science: Antiquity through the Nineteenth Century: A Biographical Dictionary with Annotated Bibliography. Cambridge, Mass: MIT Press.

Rafferty, A., \& Simons, R. (2006). An Examination of the Antecedents of Readiness for Fine-Tuning and Corporate Transformation Changes. Journal of Business and Psychology, 20(3), 325-350.

Thomas, R. \& Davies, A. (2005). What have the feminists done for us? Feminist theory and organizational resistance, Organization, vol. 12, Iss. 5, pp. 711-740.

Thurstone, L.L. (1931). The measurement of social attitudes, Journal of abonormal and social psychology, vol. 26, Iss. 3, pp. 249-269.

Thurstone, L.L. (1931). The measurement of social attitudes, Journal of abonormal and social psychology, vol. 26, Iss. 3, pp. 249-269.

Visagie, C. (2010). The Relationship between Employee Attitudes towards Planned Organizational Change and Organizational Commitment: An Investigation of a Selected Case within the South African Telecommunications Industry. A Thesis Presented to the Cape Peninsula University of Technology, in Partial Fulfillment of the Requirements for the Master of Technology.

Weber, P., \& Weber, J. (2001). Changes in Employee Perceptions During Organizational Change. Leadership and Organization Development Journal, 22(6), 291-300.

Westwood, S. (1984). All day every day: Factory and family in the making of women's, lives, Pluto press, East haven, CT.

Yousef, D. (2000). Organizational Commitment as a Mediator of the Relationship between Islamic Work Ethic and Attitudes toward Organizational Change. Human Relations, 53(4), 513. 